\title{
Mercury pollution from the past mining of gold and silver in the Americas
}

\author{
Jerome O. Nriagu \\ Department of Environmental and Industrial Health, School of Public Health, the University of Michigan. Ann Arbor, MI 48109. \\ $U S A$
}

(Received 19 March 1993; accepted 18 May 1993)

\begin{abstract}
The development of the patio amalgamation process into an industrial scale operation in 1554 stimulated the massive production of silver in the New World but left behind an unprecedented quantity of mercury pollution. The annual loss of mercury in the silver mines of Spanish America averaged 612 tonnes/year (range 292-1085 tonnes/year) between 1580 and 1900 . The production and importation of mercury into the United States ranged from 268 to 2820 tonnes/year and averaged $\sim 1360$ tonnes/year between 1850 and 1900 . Approximately $90 \%$ of the mercury consumed in the United States during this period was employed in gold and silver extraction. The cumulative losses of mercury to the environment due to the production of precious metals in the Americas totalled 257400 tonnes, with 196000 tonnes dispersed in South and Central America and 61380 tonnes in the United States. Approximately 60-65\% of the mercury lost is believed to have been released to the atmosphere, suggesting that gold and silver mines were a dominant source of atmospheric mercury pollution. Because of its high volatility, any deposited mercury can readily be re-emitted to the atmosphere. The continuing recycling of this large mass of mercury may partly be responsible for the high fluxes of mercury in many parts of North and South America and the high background levels of mercury in the global environment.
\end{abstract}

Key words: Mercury pollution; Gold; Silver; Mining

\section{Introduction}

North and South America established a hegemony on the silver market which lasted from approximately 1570 until well into this century (Del Mar, 1902; Vilar, 1969; Prieto, 1973). The stimulus for the sustained massive silver produc-

\footnotetext{
* Corresponding author.
}

tion was the introduction of a cheap and simple technology - the patio or mercury amalgamation - into silver production which was ideally suited for the low grade ores and some unique ore minerals (such as argentite and cerurgyrite) common in the region. The new 'cold' technology, often regarded as one of the most remarkable inventions of Ibero-America (Bakewell, 1984), also solved the problem of fuel scarcity which had 
plagued the various mining centers of the Americas (Brading and Cross, 1972). While the patio process supplied the silver that fueled the global economy, it also left an unparalleled legacy of massive mercury pollution. The current problem of mercury pollution associated with the gold rush in the Brazilian Amazon therefore represents a re-enactment of an old tragedy.

This report provides a quantitative estimate of the mercury discharged from the gold and silver mines of North and South America during the period of 1570-1900. The continuing impact of this old source on the global mercury cycle is discussed.

\section{Mercury amalgamation: historical outline}

Mercury amalgamation is a relatively simple and highly effective process for extracting precious metals from waste material. Although the use of the process for the recovery and refining of gold and silver was known to the Roman smiths, there is no evidence to suggest that the principle was employed in the mining of precious metals in ancient times. Vitruvius (VII, 8) referred to the use of mercury in gilding and in secondary recovery of gold: "Quicksilver is used for many purposes; without it, neither silver nor brass can be properly gilt. When gold is embroidered on a garment which is worn out and no longer fit for use, the cloth is burnt over the fire in earthen pots. The ashes are thrown into water and quicksilver added to them; this collects all the particles of gold and unites with them. The water is then poured off and the residuum placed in a cloth which when squeezed with the hands, suffers the liquid quicksilver to pass through the pores of the cloth but retains the gold in a mass within it"'. Pliny also provided explicit details about the use of mercury to recover gold:

All substances float on its (quicksilver's) surface except gold, which is the only thing that it attracts to itself. Consequently, it is also excellent for refining gold, as if it is briskly shaken in earthen vessels it rejects all the impurities contained in it. When the blemishes have been expelled, to separate the quicksilver itself from the gold it is poured out on to hides that have been well dressed, and exudes through them like a kind of perspiration and leaves the gold behind in a pure state.
The available literary information show that the use of mercury in the recovery of both gold and silver from the ores was well known in the Medieval times. al-Zuhri, for example, claimed that the Spanish mercury was exported to Abyssinia where it was used in gold mining operations (Allan, 1979); the name, Almaden, in fact is Arabic for 'the mine'. The Arab geographer, al-Idrisi, remarked that when he visited Almaden (first half of the 12th century) the mines employed 1000 laborers and had penetrated to a depth of $\sim 150 \mathrm{~m}$ (Goldwater, 1972), an indication of the high demand for mercury. In addition to the usual panning, Medieval miners employed sheep skin and mercury amalgamation to obtain the gold in alluvial deposits. An ingeneous technique described by al-Biruni (mid 11th century A.D.) involved filling holes dug on river beds with mercury which was then tapped for any gold trapped (Allan, 1979). al-Hamdani (approx. 942 A.D.) and alBiruni described, in good detail, how gold-bearing rocks were crushed, sifted, separated by washing and the gold extracted from the gangue minerals by amalgamation. al-Hamdani, in addition, provided the details about the separation of the gold from the amalgam by squeezing in a leather cloth and heating the residue to drive off the mercury. The gold nugget was called dhahab zi'baqi or dhahab muzabbaq according to al-Biruni (Allan, 1979). The nugget was further refined by cementation and the dross reamalgamated to capture the silver and any gold left over (Allan, 1979).

Theophilus' On Divers Arts (approx. 1140 A.D.) provided the following fairly succinct description of placer gold amalgamation:

\footnotetext{
There is another gold, named sand gold, which is found in the banks of the Rhine. The sands are dug up in those places where there is hope of finding gold and are put on wooden boards. Then water is repeatedly and carefully poured over them and as the sands flow off, a very fine gold remains, which is collected separately in a small pot. When the pot is half full, mercury is put in and tubbed vigorously by hand, until it is completely alloyed. Then the amalgam is put into a fine cloth, the mercury is wrung out and the residue put into a casting crucible and melted.
}

By the Middle Ages, gold amalgamation had become well entrenched as an important process in the exploitation of alluvial gold deposits. Biringuc- 
cio (1540) told us that gold prospectors used certain wooden tables made of elm, white nut or any other kind of fibrous wood whose surfaces were roughened up. Buckets of auriferous sand and water were thrown at these tables which were inclined at an angle and placed together in a long row. The heavy gold particles retained on the rough surfaces were collected in a batea and washed. "Finally, they amalgamate it (the gold) with mercury and pass it through a leather purse or cucurbit so that when the mercury has evaporated the gold remains like sand at the bottom. This gold is then mixed with a little borax, saltpeter, or black soap, melted and reduced to its own body, and later is given the shape of an ingot." (Biringuccio, 1540). For non-alluvial deposits, he reported that it was "necessary first to grind it well and make a powder of it, wash it with water in a boat or other wooden vessel, and then rub mercury on it well until all the gold has been amalgamated. In this way, the gangue material will become freed from the gold. Then by causing the mercury to pass through a leather purse or cucurbit, the gold remains separated from the mercury" (Biringuccio, 1540).

Agricola (1556) provided beautiful illustrations of various sieves, sluices, blanket-covered tables, tubs and related devices used to mine the gold in placer deposits by density separation and mercury amalgamation. Since then, only minor improvements have been made to the technique, such as the use of copper plates coated with mercury to trap the gold in the ore (Austin, 1926; Lamey, 1966; Butts and Coxe, 1967).

There are many conflicting claims about the introduction of amalgamation for beneficiating the silver ores. The technique itself can be traced back to ancient times. The Stockholm Papyrus (3rd century A.D.), for instance, contained a recipe for using mercury in the manufacture of silver (Caley, 1927). Maslima ibn Muhammad Abu 'l-Qasim alMajriti (approx. 1004 A.D.) gave a detailed description of the liquation method for parting gold from silver and concluded that "the silver which is removed from the gold in the process called shahira may be recovered merely by the addition of mercury to the earthy residue. The mercury thickens and coagulates until it becomes like a dough and... is placed in a crucible over fire and the mercury then volatilises away from the silver" (Holmyard, 1922).

Biringuccio (1540) noted that only some ores respond to mercury and advised that the silver ores "must be tested after they have been ground up to see whether they can be amalgamated with mercury, either in the same grinding mill or elsewhere. This is an excellent method if they are dry, and I know that it has been used by many with great profit". He then described the amalgamation process in detail (Biringuccio, 1540):

\footnotetext{
The substance of silver is also extracted from several ores that are pure by grinding them and then washing them and later moistening them with vinegar in which there has been some verdigris, or else moistening them with water in which sublimate, vitriol, and verdigris have been dissolved. This is done in a wooden or stone mill pan to grind the two things together with a good quantity of mercury, and by rubbing makes the mercury embrace every substance of the metals and take it into itself. Having gathered this and passed it through a deerskin purse or evaporated it with an alembic the silver or gold that is there all remains in the purse or at the bottom of the cucurbit. This way is very short and where it succeeds is very profitable.
}

The use of additives to improve the efficacy of amalgamation is particularly noteworthy as this was later to become a key feature in the patio process of South America (see below). Biringuccio described a useful and very ingenious way of extracting gold and silver from the sweepings of mints, slags of ores or contained in some ores themselves 'by sole means and virtue of mercury'. The equipment and workshop used in the Middle Ages for parting gold by amalgamation are shown in Fig. 1. In view of the excellent account provided by Biringuccio, the fact that Agricola's (1556) book 'De re Metallica' did not contain any reference to the treatment of silver ores by amalgamation could be regarded as a major oversight.

Although amalgamation was being used in silver mining in Europe by the beginning of the 16th century, its development into a versatile industrial technique in the form of the patio process was first made in New Spain (now Mexico) in 1554 by Bartolome de Medina (Prieto, 1973). The patio works consisted of a large court (patio) surrounded by installations (galera) for handling the ores and the 


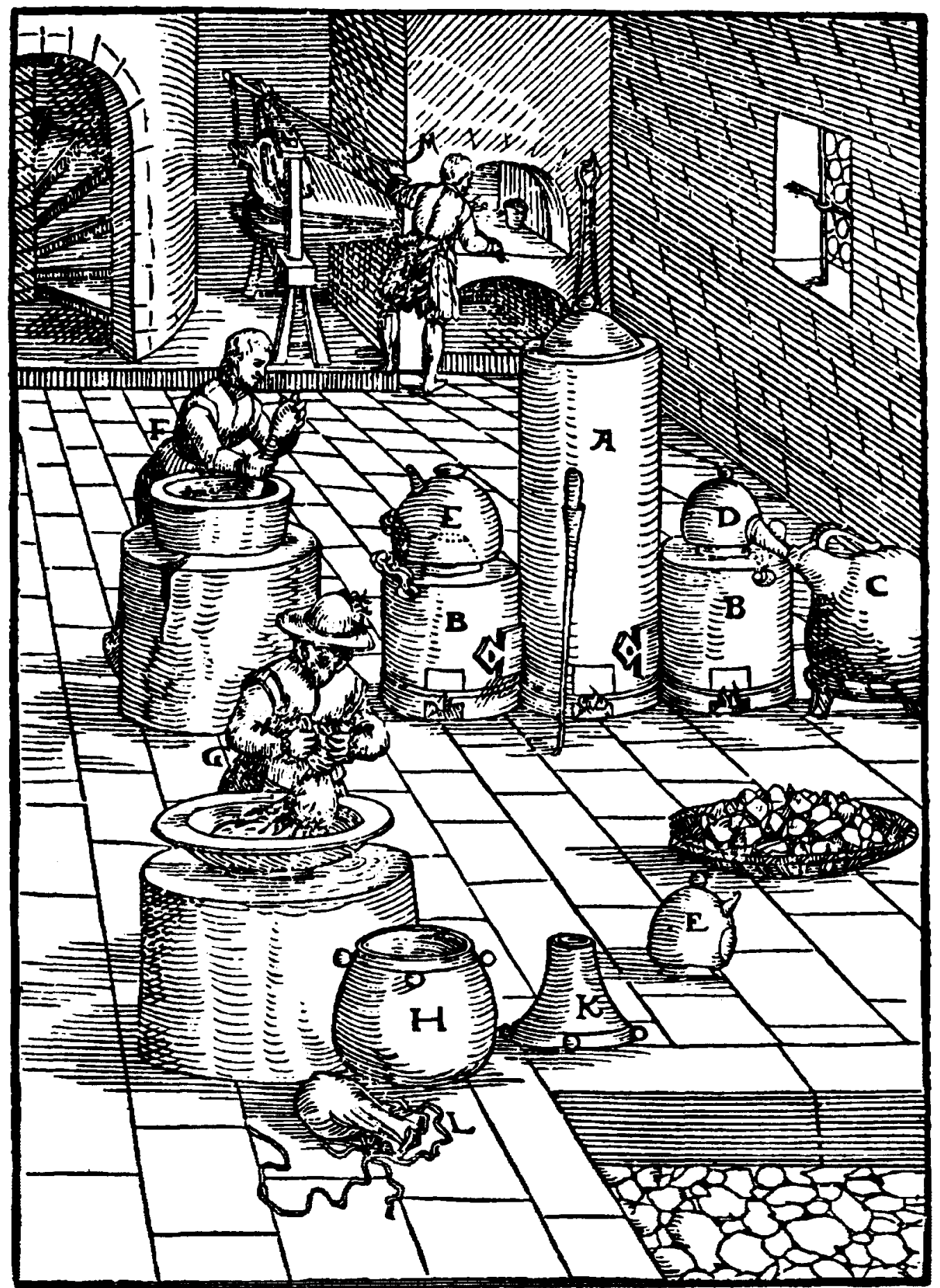

Fig. 1. Woodcut illustration of the equipment and workshop for recovering gold using the amalgam method. Of particular interest are the furnaces ( $A$ and $B$ ), the condenser $(C)$, the earthenware and iron retorts ( $D$ and $E$ ) for distilling mercury from the amalgam, the wooden mortar for purifying the mercury with salt ( $F$ and $G$ ), and the leather bag for straining the mercury off the amalgam (L) (from Ercker, 1574). 


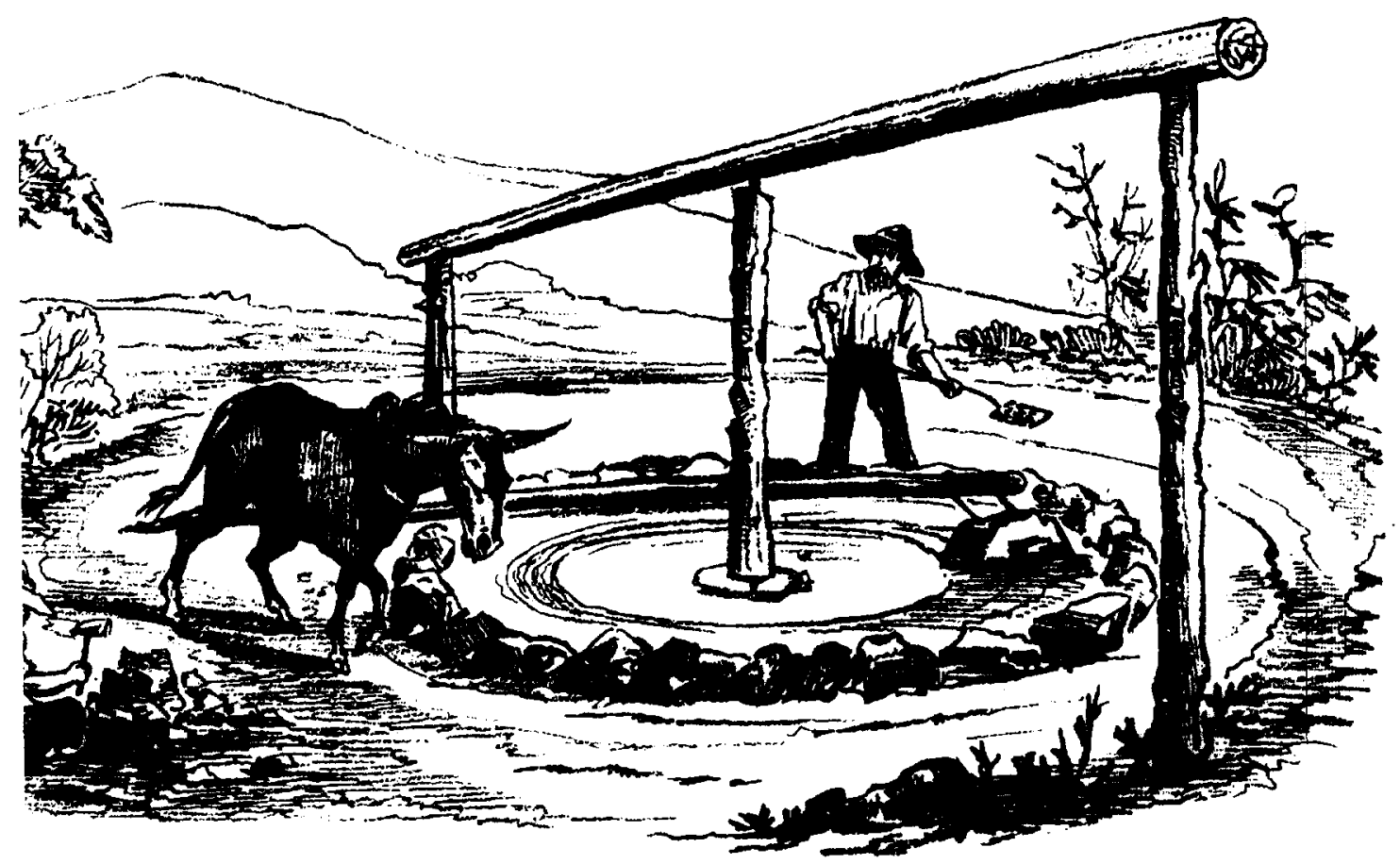

Fig. 2. A Chilian mill, the workhorse of the patio process used in silver recovery especially during the colonial times of the Americas (from Egleston, 1887).

amalgam. The process itself consisted of five separate operations. (i) The ore was crushed by means of a stamp, crusher or Chilian mill (Fig. 2) and the impure ores were sometimes crudely roasted with charcoal either in an open platform or in the same furnace (comalillos) where the amalgamation took place. (ii) The ore was then crushed, pulverized and amalgamated in an arrastra or lined pit; a typical $400 \mathrm{~kg}$ charge of ore requires $2-5 \mathrm{~kg}$ of mercury depending on the nature of the ore. (iii) The material from the arrastra and the moistened ores containing native silver or silver halides were made into a cake (torta) of 1.0-1.5 tonnes on the patio. Salt was mixed in at the rate of $\sim 1.0 \mathrm{~kg}$ per quintale, $(\sim 50 \mathrm{~kg})$ of ore and lime was added if the mixture turned 'hot', but if no heat was generated, the magistral (roasted copper or iron sulfate) was used. Mercury was then mixed in $(-6-8 \mathrm{~kg} / \mathrm{kg}$ of silver in the ore) and the mixture treaded at intervals by men, horses or mules. The reaction of the mercury and silver took 3 weeks to 5 months depending on the ambient temperature, the nature of the ore and the refining skills of the azoguero or beneficiador. In the Potosi region of the Andes mountains where the temperatures are usually low, the related Cazo processes were perfected in which the reaction was speeded up by warming the mixture in large stone tanks (cajones) or the copperbottomed tubs invented by Alonso Barba in 1590 (Barba, 1640). (iv) The finished cakes were shovelled into a large vat (tina) equipped with beaters to separate out the silver amalgam (pella). Before that, a large quantity of mercury in excess of that required for amalgamation was sometimes added to coagulate the dispersed mercury, make the amalgam more fluid and arrest any further reaction of the reagents with the amalgam. (v) Excess mercury was expelled from the pella in canvas bags and the amalgam heated in a retort (capellinas) to free the silver and recover some of the mercury.

The patio and Cazo processes and their various adaptations made it possible for large amounts of 
ores containing as low as $\mathbf{4 0 0} \mathrm{g}$ silver per tonne of ore to be extracted profitably, a performance unmatched by any of the smelting techniques being used in Europe at that time. The German miner, Friedrich Sonneschmidt who was sent in 1788 to introduce new smelting techniques to South America quickly became an ardent advocate of the indigenous process: "for more than two centuries Spanish America has possessed the secret of reducing, by an ingenious operation the better part of silver ores to pure silver... I have no embarrassment in declaring that with ten years of work, and no matter how many methods I have attempted, I have not been able to introduce either the refining process of $M$. de Bohn or any other process preferable to the patio" (Motten, 1972). He noted that although the process was slow, it was cheap, needed little water and no firewood, used simple tools, could be set up almost anywhere and could be taught even to the ignorant. No wonder the patio process remained unchallenged in South America for over 300 years; as late as $1870, \sim 71 \%$ of the silver in South America was still being produced by this process (Brading and Cross, 1972).

It must be noted that smelting and recovery of silver by lead cupellation persisted throughout the colonial times. Such techniques were preferred for rich ores where lead was present (Panczner, 1992) and by poor miners and the Indian laborers who received the ore as part of their wage (Bethel, 1984). A discussion of silver smelting, which remained very much a secondary process, is outside the primary forus of this report, however.

Gold and silver mining in colonial North America likewise was based on the patio processes. The Orange Grove (Vaucluse) mine in Virgina, one of the best organized gold-mining operations in North America before 1850 was typical: "the small or fine ores are ground in the Chilian mills (Fig. 2) with water... At the end of every twelve hours the mills are cleaned out, taking all the residuum of the ore, in which are the gold and quicksilver, having formed an amalgam... this residuum is placed in a strong iron-bound box,... (and) is washed out or rocked down in a machine for the purpose, where the gold amalgamates and the amalgam of gold and quicksilver is obtained and washed clean, which is then strained through buckskin or fine Nankeen, expressing all the superflous mercury" (Hazen and Hazen, 1985). During the gold rush in the western North America, a new (pan) process slowly evolved (Egleston, 1887):

\begin{abstract}
As gold grew scarcer, silver ores were looked for and became an object of great interest. At first only the rich outcrops of the free-milling lodes were worked. The ores from them were treated by the old Patio processes, which are still in use in Mexico and are characterized by the use of arastras and Chilian mills. Occasionally the Cazo method was adopted by some people who had seen it or had heard of its working in Chile. The Cazo method, working quicker than the Patio, was adopted in some places; the bottom of the box was replaced by iron, and then the sides, and then the idea of grinding suggested itself until the amalgamation pan in all its varieties grew up little by little. It was at first thought that the pan could be used equally well for both grinding and amalgamating, and some people still use it for both purposes.
\end{abstract}

In 1786, the Hungarian Baron Inigo de Born modified the Cazo process into a chloride roastbarrel amalgamation technique for the more complex silver ores of Europe. For treating the complex Comstock Lode ores of Nevada, the Washoe hot-pan amalgamation process was invented in 1861 in which the pulverized ore was steam-heated and mulled with mercury, salt, copper sulfate and sulfuric acid in a cast iron pan. Modifications of the pan amalgamation processes for dealing with specific ores included the Tina, Fondon, FranckeTina, Boss, Reese River and Kroehnke processes (Egleston, 1887; Lamey, 1966). Although the cyanide process was introduced in Witwatersrand in 1890 to recover the gold left in the pulp after amalgamation, the technological nexus between silver and mercury was never fully severed. The continuing use of large quantities of mercury by the gold miners in the Brazilian Amazon clearly attests to this fact.

\section{Loss of mercury during silver and gold recovery}

An adequate supply of mercury was unquestionably the key raw material in the refining of silver by patio amalgamation. Although some of the mercury used to extract the silver was recovered, a large fraction was generally wasted in the process 
Table 1

Domination of silver production by South and Central America between 1493 and 1850 (Lamey, 1966)

\begin{tabular}{lcccl}
\hline Period & \multicolumn{3}{l}{ Percentage of global silver production } \\
\cline { 2 - 5 } & Bolivia & Peru & Mexico & $\begin{array}{l}\text { Regional } \\
\text { Total }\end{array}$ \\
\hline $1493-1600$ & 48 & 13 & 12 & 72 \\
$1601-1700$ & 36 & 26 & 24 & 86 \\
$1701-1800$ & 12 & 20 & 57 & 88 \\
$1801-1850$ & 9.5 & 15 & 57 & 81 \\
\hline
\end{tabular}

because of carelessness on the part of the miners and the crude equipment and conditions. Considerable quantities of mercury were needed to sustain the massive output of silver from the American mines (Table 1) and the great cycles of silver production were closely linked to the supply and price of the mercury (Ransome, 1919; Fisher, 1977; Blanchard, 1989). It was estimated that a large operation with 60 -stamp mills which processed 3-4 tonnes of ore per stamp per day would require about $600-900 \mathrm{~kg}$ of mercury per day, with the cost of the mercury supply estimated to be $\$ 30000-\$ 40000$ per year (Egleston, 1887). During 1873, the Brunswick mill (Nevada) alone used up about 28 tonnes of mercury (Egleston, 1887). In general, the mercury loss represented $10-40 \%$ of the cost of silver production, depending on the mining center, the price of mercury at the time and the experience of the miner or company (Egleston, 1887; Reading and Cross, 1972; Fisher, 1977; Blanchard, 1989).

Loss of mercury occurred at many stages during the mill operation. The mercury was transported in leather bags which often broke (Cobb, 1949). In the mills, the mercury was moved in pails and buckets with unavoidable spillage. Carelessness in the charging of mercury into mills, barrels and pans often resulted in mercury loss; $>500 \mathrm{~kg}$ of it was once discovered in the foundations under the pans of one company in Colorado (Egleston, 1887). Most of the mercury loss, however, occurred during the stamping, grinding, separation of the amalgam, retorting and refining of the gold and silver bullion. The loss during these processes was determined by factors which influenced the ability of silver to bind to the mercury and the efficiency of the technology being used to recover the amalgam. The formation of insoluble compounds by the reaction of mercury with the sulfide, chloride and other salts in the ores often aggravated the loss. With repeated use, the mercury sometimes became 'greasy' and had to be dumped (Egleston, 1887). Because of the large loss of both mercury and silver during the separation of the amalgam, various attempts were made to pass the tailings over revolving blankets, rubbers, amalgamated plates and many other contrivances but 'they are not as yet successful in the commercial sense' (Egleston, 1887) in recapturing the silver and mercury.

Until the middle of the 18th century, a rule of thumb in Potosi (now Bolivia) was that $1.5 \mathrm{~kg}$ of mercury was lost for every $1 \mathrm{~kg}$ of silver produced (Brading and Cross, 1972; Fisher, 1977). The ratio (or correspondencia), however, could be as low as $0.85 \mathrm{~kg} \mathrm{Hg} / \mathrm{kg} \mathrm{Ag}$ for impoverished ores and as high as $4.1 \mathrm{~kg} \mathrm{Hg} / \mathrm{kg} \mathrm{Ag}$ for very rich ores. Because of a depressed mercury price during 1760-1810, the loss of $2.4-2.9 \mathrm{~kg} \mathrm{Hg} / \mathrm{kg}$ of silver produced became common in many mining districts (Blanchard, 1989). The correspondencia for the colonial silver mines were quite similar to the current loss of mercury associated with the modern sluicing, hydraulic mining and dredging employed in gold extraction in the Amazon of Brazil which has been estimated to be in the typical range of 1.3-1.7 $\mathrm{kg} / \mathrm{kg}$ of gold recovered (Pfeiffer et al., 1989; Cleary, 1990, Lacerda and Salomons, 1991).

Even with the many technical innovations, the loss of mercury in the mills of Western United States remained substantial and generally varied from $0.3-3.0 \mathrm{~kg} /$ tonne of silver ore treated. For example, the Pelican mill (Georgetown, Colorado) which employed barrel amalgamation, lost $\sim 1.0$ $\mathrm{kg}$ of $\mathrm{Hg}$ during each charge of 1 tonne of ore (Egleston, 1887). For pan amalgamation at the Stewart's Mill (Georgetown, Colorado), the loss was $\sim 1.0 \mathrm{~kg} /$ tonne of ore, at the Nederland mill (Boulder, Colorado) 0.5-1.0 kg, at the Brunswick Mill (Nevada) it was $1.0 \mathrm{~kg}$ and at Eureka Mill (Nevada) the loss was $\sim 0.7 \mathrm{~kg} /$ tonne ore treated (Egleston, 1887). For several other 
mills in Nevada, $\sim 0.5-1.4 \mathrm{~kg}$ of mercury was lost per tonne of ore (Egleston, 1887).

\subsection{Estimate of losses in South and Central America}

Virtually all the mercury used in Spanish America came from three sources: Almaden mines in southern Spain from which Mexico got most of her supplies, Huancavelica mines in central Peru which provided the mercury to South America and the Idria mines in modern Slovenia which was tapped occasionally to make up any shortfalls from the two principal sources (Fisher, 1977; Bethell, 1984; Blanchard, 1989). During the late 19th century, a number of mercury deposits in Mexico were also mined to meet some of the local demand.

Since nearly all the mercury produced in Almaden and Huancavelica went to the silver refineries in South America, the loss of mercury can been estimated using the production figures from these two sources and the recorded imports from the Idrija mines (Cronshaw, 1921; Brading and Cross, 1972; Fisher, 1977; Bethell, 1984; Blanchard, 1989). The close linkage between silver

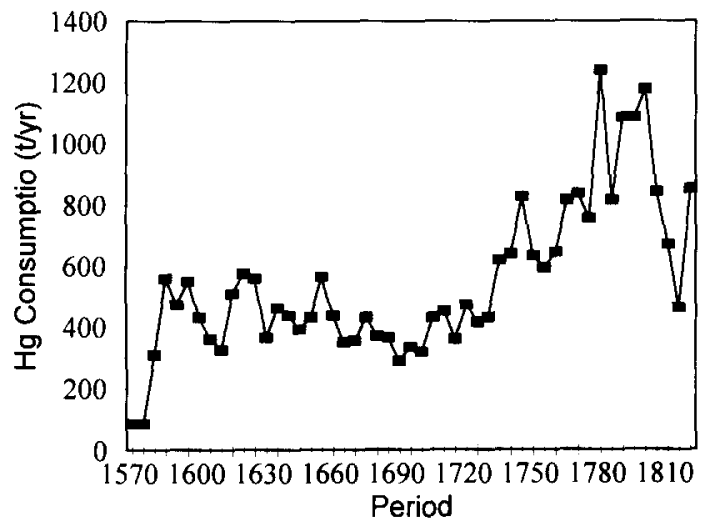

Fig. 3. Mercury losses from the refining of silver in colonial South America. The consumption and discharge of mercury each year is derived from the mercury output by the Huancavelica mines, $85 \%$ of the output by the Almaden, and any imports from the Idrija mines. Based on various compilations, especially by Vilar (1976), Bakewell (1984), Motten (1972), Whitaker (1952), Brading and Cross (1972), Blanchard (1989), Fisher (1977), Bethell (1984) and Panczner (1992). production and mercury consumption provided a barometer in determining the quantity of mercury employed by the miners (von Humboldt, 1818). During 1556-1560, $\sim 9$ tonnes/year of mercury were consumed in the silver mines and by $1570-1575$, following the discovery of the Huancavelica mercury deposits in 1563, the demand had exceeded 86 tonnes/year (Vilar, 1963). Between 1580 and 1820 , the calculated consumption and loss of mercury (Fig. 3) varied from 292 to 1085 tonnes/year with the average being 527 tonnes/year. By comparison, the input of mercury into the Amazon associated with the current gold rush is reported to be 90-120 tonnes/year (Lacerda and Salomons, 1991; Nriagu et al., 1992). The cumulative loss of mercury in South America between 1570 and 1820 is estimated to be 126000 tonnes, from Fig. 3.

Total silver production in South and Central America between 1820 and 1900 is estimated to be 99400 tonnes, based on the compilations by Moshide (1985), Cronshaw (1921) and Lamey (1966). Assuming the ratio of mercury lost to silver produced to be 1:1 (less than the ratios in colonial times) and that $70 \%$ of the silver was recovered by the patio process and its modifications (see above), the cumulative consumption of $\mathrm{Hg}$ during the 80 years is estimated to be 70000 tonnes. From the total figure, the average discharge rate in postindependence times is estimated to be 875 tonnes/year. Thus, for 320 years, from 1570 to 1900 , when the patio process was in common use, the discharge of mercury from silver mining in South and Central America averaged 612 tonnes/year and totalled $\sim 196000$ tonnes, an impressive figure indeed.

\subsection{Estimate of losses in the United States}

The history of North America is laced with the usual quest for silver and gold. The Appalachian goldfields were the first to be exploited by the early settlers. Prior to 1825 , most of the gold produced by the colonies came from North Carolina. Gold deposits were later discovered in South Carolina and Virginia in 1829, Alabama in 1830, and Tennessee in 1831 (Hazen and Hazen, 1985). Most of the gold in these states occurred in alluvial deposits or in veins and stringers and hence were 
amenable to mercury treatment: 'The preferred method of gold recovery at American vein mines throughout the 1830 s and 1840 s was stamping and amalgamation process' noted Hazen and Hazen (1985). Any gold which occurred in sulfide could not be recovered by the amalgamation process and was discarded. Although an abortive effort was made in 1848 to introduce smelters for the sulfide ores, amalgamation with all its limitations remained the predominant recovery technique for hardrock ores before the civil war (Hazen and Hazen, 1985). Most of the mercury used in the Appalachian gold fields was imported from Spain (Egleston, 1887; Hazen and Hazen, 1985).

The gold rush to California that began in 1848 prompted the discoveries of major gold deposits in Comstock, Nevada in 1859; Black Hills, South Dakota in 1876; Cripple Creek, Colorado and Nome, Alaska in the 1890s; and the Cariboo district of British Columbia in the 1860s and 1870s (Rickard, 1932). As a result, gold production increased from $\sim 43000 \mathrm{oz}$ in 1847 to $\sim 2.9$ million oz in 1852 (US Bureau of Census, 1961). The gold rushes to the western states drew people from all over the world and were instrumental in the transfer of the mercury amalgamation technology to other countries especially Australia and Canada (Rickard, 1932; Lamey, 1966). It may be noted that the sluices, rifles, hyraulic dredges and elevators, and many other accoutrement of the

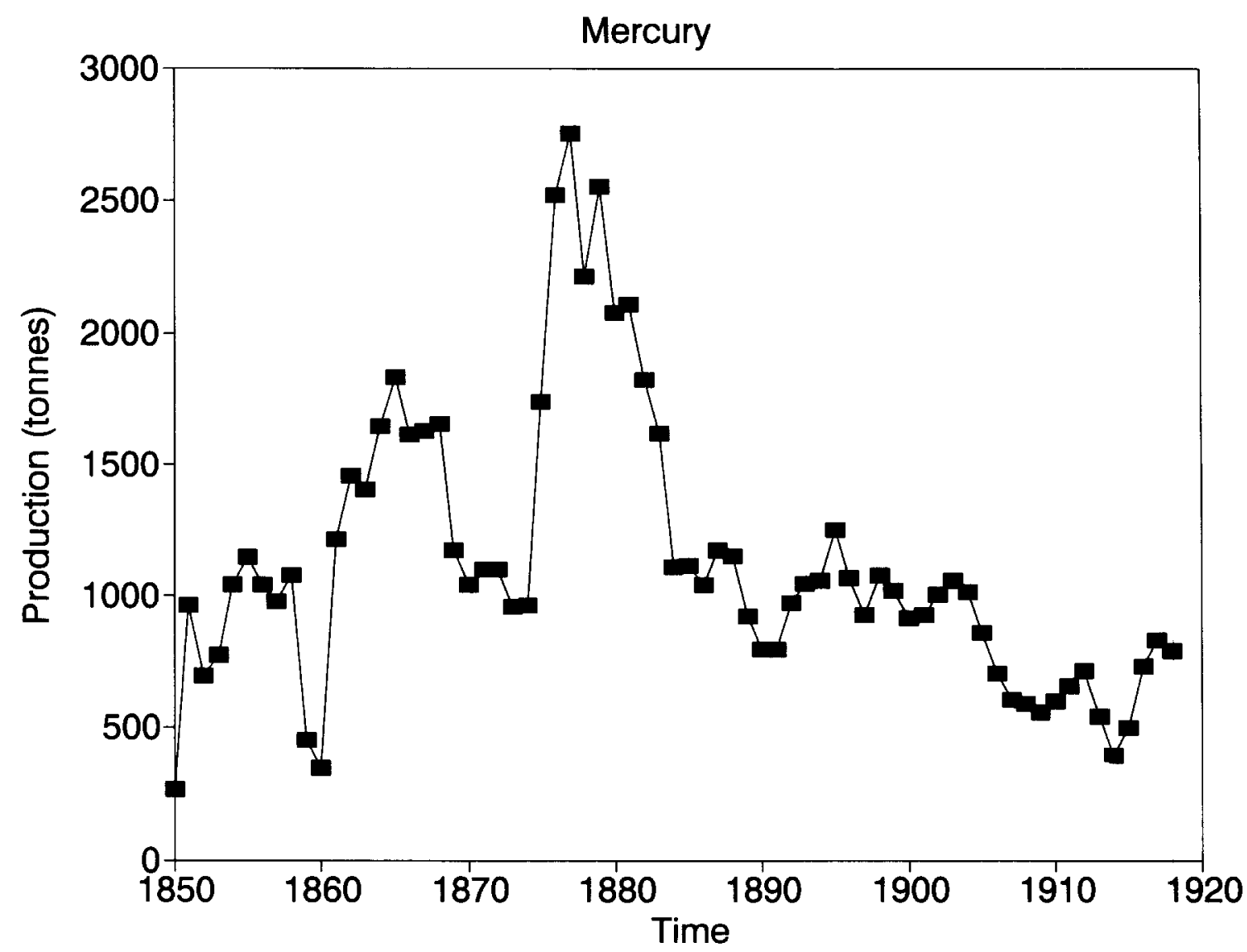

Fig. 4. Production of mercury by mines in the United States (primarily from California) between 1850 and 1900 . Based on the compilations in the US Geological Survey (1918) and Ransome (1919). 
gold miners in the Brazilian Amazon were originally developed in the goldfields of western Canada and the United States.

The early settlers could not find any major silver deposits in Eastern and Central United States. Although many lead deposits in the United States were mined, primarily to obtain the lead for bullets, most of the lead ores proved to be devoid of silver. Silver production in North America was therefore insignificant before 1850 and totalled only 426000 fine oz (Hazen and Hazen, 1985). With the discovery of the famous Compstock deposits (Nevada) in 1859, silver production jumped from $\sim 39000 \mathrm{oz}$ in 1858 to $\sim 1.5$ million oz in 1861 and to over 8.5 million oz in 1864 . Subsequent developments of the major silver deposits in
Arizona, California, Colorado, Idaho, Montana, New Mexico and Utah saw the silver production rise to 20 million oz in 1872,30 million in 1876 and 50 million oz in 1890 (US Bureau of Census, 1961). Thus, by the second half of the 19th century, the United States had supplanted Mexico and South America as the leading producer of both gold and silver.

The availability of cheap local sources of mercury was also a key factor in the development of the precious metal resources of the western states. The huge New Almaden cinnabar (mercury sulfide) deposit was discovered in 1845 and mining commenced in 1847 to meet the avid demand by the gold and silver miners. Mercury production from this mine exceeded 260 tonnes in 1850 and

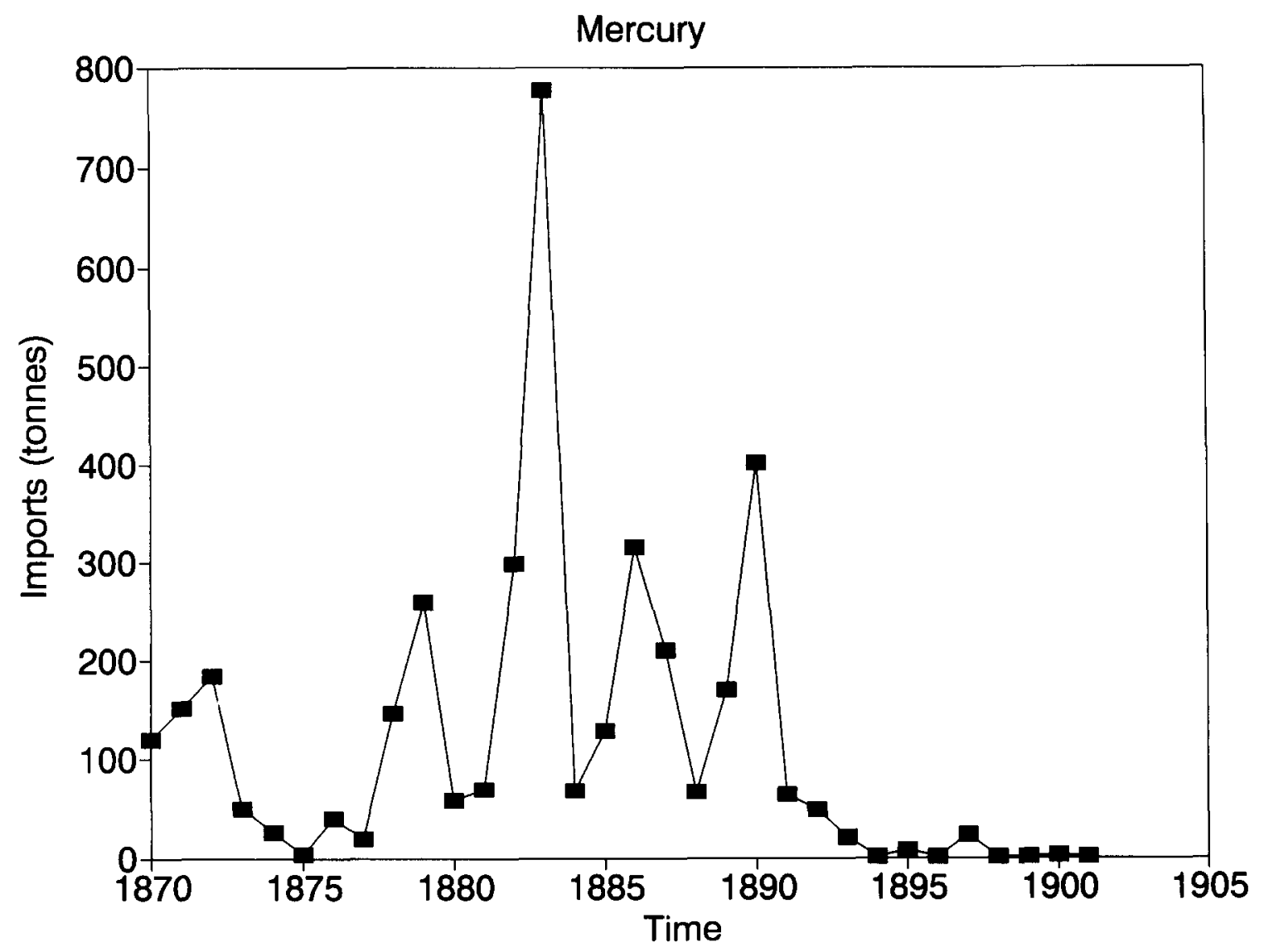

Fig. 5. Importation of mercury into the United States between 1860 and 1900 . 
reached 960 tonnes a year later. Subsequently, mercury deposits were discovered in other parts of California including the New Idria (1858), Redington (1862), Sulfur Bank (1874) and Pope Valley (1864) districts (Lamey, 1966). With the exception of the Terlingua mine of Texas which came into operation in 1895 , most of the mercury produced in the United States before 1900 came from the mines in California.

The history of mercury production in the United States (mainly in California) from 1850 to 1918 is depicted in Fig. 4. The output was lowest (268 tonnes) in 1850 , peaked in 1877 at $\sim 2760$ tonnes, and averaged $\sim 1290$ tonnes/year between 1850 and 1900 . The massive local production was not always enough to meet the demand and large quantities of mercury were also imported into the country especially between 1870 and 1893 (Fig. 5). The imports ranged from 0.1 to 401 tonnes/year and averaged 75 tonnes/year. Between 1850 and 1900 , the total consumption (production + import) of mercury in the United States varied from 268 to 2820 tonnes/year and averaged 1360 tonnes/year. The cumulative production of 64000 tonnes combined with the imports of 3730 tonnes, gives the total mercury consumption of 68200 tonnes during that period.

The reduced consumption of mercury from $\sim 1890$ may be related to the introduction of the cyanide process and the discovery of rich silverbearing ores (especially the sulfides) which were more amenable to the normal smelting technologies (Egleston, 1887). Although the silver and gold were being produced as byproducts from the smelting of copper, lead and zinc ores, $\sim 60 \%$ of the precious metals came from placer deposits and dry or siliceous ores that still required mercury (Cronshaw, 1921; Bateman, 1942; Lamey, 1966). By 1905 or so, the cyanidization process had supplanted mercury amalgamation in the beneficiation of precious metals in the United States. Nevertheless, gold-quartz milling alone in the country required $\sim 27$ tonnes of mercury between 1913 and 1916 (US Geological Survey, 1890-1900).

As a first approximation, it is assumed that $90 \%$ of all the mercury produced and imported by the United States between 1850 and 1900 was used in the recovery of gold and silver. The mercury discharged to the environment associated with this particular activity is accordingly estimated to be 240-2540 tonnes/year with the average being 1220 tonnes/year. The cumulative amount lost to the atmosphere from the precious metal mines is estimated to be 61380 tonnes. By comparison, the average emission rate in South and Central America between 1820 and 1900 is estimated to be 875 tonnes/year (see above).

\section{Environmental implications}

From the cumulative losses in South and Central America (196000 tonnes) and North America (68 200 tonnes), the total amount of mercury released into the environment from the gold and silver mines is estimated to be 264200 tonnes. The mercury was used in numerous silver and gold mines in various parts of the two continents. Most of the mines have since been abandoned. Expectedly, the most intense losses occurred in the regions with major sustained silver production for a long time. Seven of the key regions in South America and the 16 in Central America are shown in Fig. 6. The many famous mines in the United States where gold and silver were amalgamated included Comstock and Tonopath (Nevada), Butte (Montana), Tintic and Park City (Utah), Bunker Hill and Coeur d'Alene (Idaho), Leadville and Cripple Creek (Colorado), Tombstone (Arizona), Socorro and Mogollon counties (New Mexico), the Great Mother Lode and other areas in the lower slopes of the Sierra Nevada Mountains of California (Phillips and Louis, 1896; Egleston, 1887; Cronshaw, 1921; Bateman, 1942).

Very little is currently known about the fate and effects of the unprecedented quantities of mercury discharged in the silver and gold mining areas. It would seem reasonable to assume that $10 \%$ of the mercury supply was lost during transport, storage and handling (Cobb, 1949; Bakewell, 1984). In general, $-25-30 \%$ of the mercury was lost as flour in the waste water or was left behind in the tailings and other residues (Egleston, 1887; Brading and Cross, 1972). Over the years, the mercury could turn the accumulated piles of slags and residues from the patio floor and amalgamation 


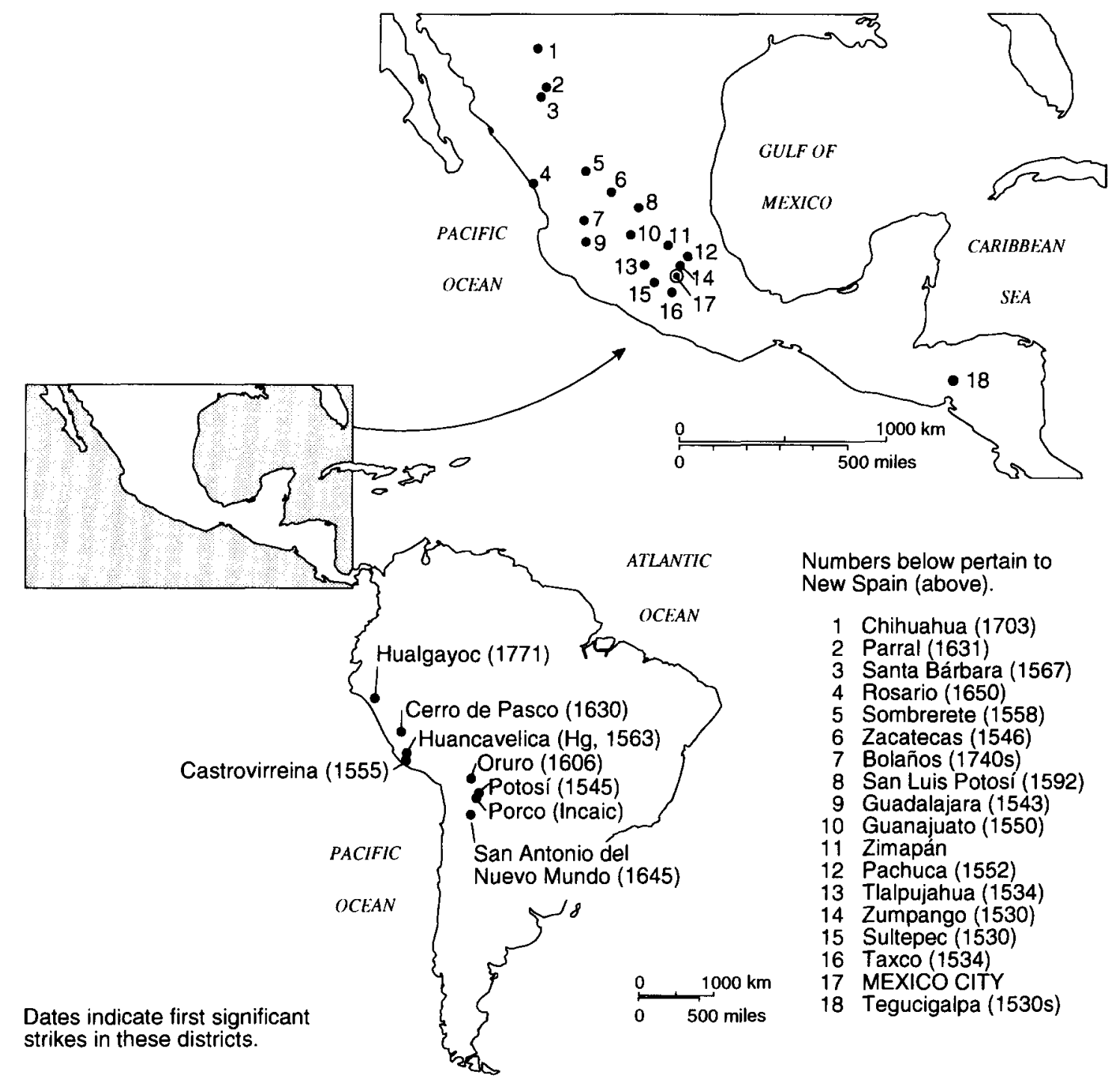

Fig. 6. Major silver mining centers in colonial South and Central America (based on Prieto, 1973; Bethell, 1984; Panczner, 1992).

pans into what was described by Lacerda and Salomons (1991) as 'chemical time bombs'. The slags and mine wastes presumably continued to slowly exhale some of the mercury to the atmosphere. Under the hot tropical conditions, especially in Mexico, some of the mercury in the tailings could also become methylated and then vented to the atmosphere (Lindberg and Turner, 1977; Swain et al., 1992). It is really surprising that little has been done to study the persistence of mercury in these chemical time bombs, the environmental impacts, and long-term dispersal of the huge mercury reservoirs in some of the old mining centers.

The balance of the mercury lost $(60-65 \%)$ would have been released to the atmosphere during (a) the dry-milling process, (b) the amalgamation process on the open patio floor or in heated 
cauldrons, (c) the squeezing of the pella (amalgam) to remove the excess mercury and (d) the burning of the mercury amalgam. The fractional loss of mercury to the atmosphere in the past is comparable with the $65-83 \%$ emission figure for current recovery of gold in the Amazon (Malm et al., 1990; Lacerda and Salomons, 1991).

In this report, $60 \%$ has been adopted in calculating the quantity of mercury that was released to the atmosphere. From the data shown in Fig. 3, the atmospheric fluxes of mercury from the silver mining in colonial South America during 1587-1820 are estimated to have varied from 175-650 tonnes/year. The average rates were 316 tonnes/year during 1587-1820 and 525 tonnes/year during 1821-1900. The atmospheric emission rates in United States varied from 208 to 1660 tonnes/year and averaged 780 tonnes/year between 1850 and 1900 . The average figure for the United States exceeds the 260-600 tonnes/year estimated to be the current total emissions of mercury to the atmosphere by industries in that country (Cole et al., 1992; Voldner and Smith, 1989). Also, the average figure of 1305 tonnes/year for the Americas may be compared with the present-day global emissions of 910-6200 tonnes/year by various industries (Nriagu and Pacyna, 1988). The silver and gold mines certainly would have exercised a more dominant influence on the global and regional atmospheric mercury cycle before the turn of this century.

The cumulative amounts of mercury cycled through the atmosphere from the precious metal mines are estimated to be 118000 tonnes in South and Central America and 38000 tonnes in the United States. The importance of this 'new' source has not been considered in previous discussions of the global and regional cycling of mercury (Andren and Nriagu, 1979; Lindquist et al., 1991). Such a source can, in fact, explain the elevated mercury levels found in the Antarctic snowfields (Vandal et al., 1993) and in the marine environment of the Southern Hemisphere (Fitzgerald, 1986; Kim and Fitzgerald, 1986; Mason and Fitzgerald, 1990; Slemr and Lange, 1992). Because of its high volatility, any deposited mercury can readily be re-emitted and the grasshopper-type dispersal pattern can result in the same mercury being cycled through the atmosphere for a long time. An analogy can be drawn with a number of pesticides, such as PCB and DDT. Although the use of such compounds have been banned in North America for several years, they are still being remobilized in large amounts and dispersed through the atmosphere (Voldner and Smith, 1989; Baker et al., 1993). A re-emission of only $0.2 \%$ of the mercury lost in the United States would amount to a substantial fraction of the 260-600 tonnes/year currently being released by anthropogenic sources in the country. The increasing rates of atmospheric mercury deposition reported in midcontinental North America (Nater and Grigal, 1992; Swain et al., 1992) presumably reflects the continuing leapfrogging of the mercury from the past silver and gold mining activities. In view of the relatively long residence time $(\sim 6-18$ months) of mercury in the atmosphere (Lindberg, 1986) and the ease with which previously deposited mercury can be mobilized and retransmitted, it would seem likely that the Spanish American silver mines were partly responsible for the high background concentrations of mercury now being reported in the global environment (Nriagu, 1989; WHO, 1991).

\section{References}

Agricola, G., 1556. De re Metallica. Translated by H.C. Hover and L.H. Hoover, 1950. Dover Publications, New York.

Allan, J.W., 1979. Persian Technology 700-1300 AD. Ithaca Press, London.

Andren, A.W. and J.O. Nriagu, 1979. The global cycle of mercury. In: J.O. Nriagu (Ed.), Biogeochemistry of Mercury in the Environment. Elsevier, Amsterdam, pp. 1-21.

Austin, L.S., 1926. The Metallurgy of the Common Metals. John Wiley \& Sons, New York, pp. 229-248.

Baker, J.L., T.M. Church, S.J. Eisenreich, W.F. Fitzgerald and J.R. Scudlark, 1993. Relative Atmospheric Loadings of Toxic Contaminants and Nitrogen to the Great Waters. Report prepared for Pollution Assessment Branch, Office of Air Quality Planning and Standards, US Environmental Protection Agency, Research Triangle Park, North Carolina, $142 \mathrm{pp}$.

Bakewell, P., 1984. Miners of the Red Mountain. Univ. of New Mexico Press, Albuquerque.

Barba, A.A., 1640. Arte de los Metales. Translated by R.E. Douglas and E.P. Mathewson, 1923. Wiley, London.

Bateman, A.M., 1942. Economic Mineral Deposits. John Wiley \& Sons, New York. 
Bethell, L., 1984. Mining in Colonial Spanish America. In: L. Bethell (Ed.), The Cambridge History of Latin America. Cambridge Univ. Press, Cambridge, pp. 105-151.

Biringuccio, V., 1540. Pirotechnia. Translated by C.S. Smith and M.T. Gnudi, 1942. MIT Press, Cambridge, MASS.

Blanchard, I., 1989. Russia's Age of Silver. Routledge, London.

Brading, D.A. and H.E. Cross, 1972. Colonial silver mining: Mexico and Peru. Hispanic Am. Hist. Rev., 52: 545-579.

Butts, A. and C.D. Coxe, 1967. Silver. Van Norstand, New York.

Caley, E.R., 1927. The Stockholm Papyrus. J. Chem. Educ. 4: 979-1002.

Cleary, D., 1990. Anatomy of the Amazon Gold Rush. Univ. of Iowa Press, Iowa City.

Cobb, G.B., 1949. Supply and transportation for the Potosi mines, 1545-1640. Hispanic Am. Historical Rev., 29: 25-45.

Cole, H.S., A.L. Hitchcock and R. Collins, 1992. Mercury Warning: The Fish You Catch May be Unsafe to Eat. Clean Water Fund, Washington, D.C., 61 pp.

Cronshaw, H.B., 1921. Silver Ores. John Murray, London.

Del Mar, A., 1902. A History of the Precious Metals. Reprinted by A.M. Kelley, New York, 1969.

Egleston, T., 1887. The Metallurgy of Silver, Gold and Mercury. John Wiley \& Sons, New York.

Ercker, L., 1574. Treatise on Ores and Assaying. Translated by A.G. Sisco and C.S. Smith. Univ. of Chicago Press, Chicago.

Fisher, J.R., 1977. Silver Mines and Silver Miners in Colonial Peru, 1776-1824. Centre for Latin American Studies, Univ. of Liverpool.

Fitzgerald, W.F., 1989. Atmospheric and oceanic cycling of mercury. In: J.P. Riley and P. Chester (Eds), Chemical Oceanography. Academic Press, London, pp. 152-187.

Goldwater, L.J., 1972. Mercury: A History of Quicksilver. York Press, Baltimore, Maryland, 302 pp.

Hazen, M.H. and R.M. Hazen, 1985. Wealth Inexhaustible, A History of America's Mineral Industries to 1850. Van Nostrand Reinhold, New York.

Holmyard, E.J., 1922. Arabic chemistry. Nature, 109: 778-779.

Kim, J.P. and W.F. Fitzgerald, 1986. Sea-air partitioning of mercury in equatorial Pacific Ocean. Science, 231: 1131-1133.

Lacerda, L.D. and W. Salomons, 1991. Mercury in the Amazon. Dutch Ministry of Housing, Physical Planning \& Environment Report, Institute of Soil Fertility, Haren, The Netherlands.

Lamey, C.A., 1966. Metallic Industrial Mineral Deposits. McGraw-Hill, New York.

Lindberg, S.E. and R.R. Turner, 1977. Mercury emissions from chlorine-producing solid waste deposits. Nature, 268: 133-136.

Lindberg, S.E., 1986. Mercury vapor in the atmosphere: three case studies on emission, deposition and plant uptake. Adv. Environ. Sci. Technol., 17: 535-560.

Lindquist, O. et al., 1991. Mercury in Sweden: Recent research on causes, consequences and corrective methods. Water, Air Soil Pollut., 55: 1-261.

Malm, O., W.C. Wolfgang, C.M.M. Souza and R. Reuther,
1990. Mercury pollution due to gold mining in the Madeira River Basin, Brazil. Ambio, 19: 11-15.

Mason, R.P. and W.F. Fitzgerald, 1990. Alkylmercury species in the equatorial Pacific. Nature, 347: 457-459.

Mohide, T.P., 1985. Silver. Ontario Mineral Policy Background Paper No. 20, Ministry of Natural Resources, Toronto.

Motten, C.G., 1972. Mexican Silver and the Enlightenment. Octagon Book, New York.

Nater, E.A. and D.F. Grigal, 1992. Regional trends in mercury distributions across the Great Lakes states, north central USA. Nature, 358: 139-141.

Nriagu, J.O. and J.M. Pacyna, 1988. Quantitative assessment of worldwide contamination of air, water and soils by trace metals. Nature, 333: 134-139.

Nriagu, J.O., 1989. A global assessment of the natural sources of atmospheric trace metals. Nature, 338: 47-49.

Nriagu, J.O., W.C. Pfeiffer, O. Malm, C.M.M. Souza and G. Mierle, 1992. Mercury pollution in Brazil. Nature, 356: 389.

Panczner, W.D., 1992. Minerals of Mexico. Van Nostrand Reinhold, New York.

Pfeiffer, W.C., L.D. Lacerda, O. Malm, C.M.M. Souza, E.G. Silveira and W.R. Bastos, 1989. Mercury concentrations in inland waters of gold-mining areas in Rondonia, Brazil. Sci. Total Environ., 87: 233-240.

Phillips, J.A. and H. Louis, 1896. A Treatise on Ore Deposits Macmillan, London, $941 \mathrm{pp}$.

Pliny. Natural History. Translated by H. Rackham. Harvard Univ. Press, Cambridge, MASS.

Prieto, C., 1973. Mining in the New World. McGraw-Hill, New York.

Ransome, F.L., 1919. Quicksilver in 1918. US Geological Survey, Department of the Interior, Government Printing Office, Washington D.C.

Rickard, T.A. 1932. A History of American Mining. McGrawHill, New York, 419 pp.

Slemr, F. and E. Langer, 1992. Increase in global atmospheric concentrations of mercury inferred from measurements over the Atlantic Ocean. Nature, 355: 434-437.

Swain, E.B., D.R. Engstrom, M.E. Brigham, T.A. Henning and P.L. Brezonik, 1992. Increasing rates of atmospheric mercury deposition in midcontinental North America. Science, 257: 784-787.

US Bureau of Census, 1961. Historical Statistics of the United States, Colonial Times to 1957. U.S. Dept. of Commerce, Washington, D.C.

U.S. Geological Survey, 1890-1990. Mineral Resources of the United States. US Department of the Interior, Government Printing Office, Washington, D.C., Annual Volumes.

Vandal, G.M., W.F. Fitzgerald, C.F. Boutron and J.P. Candelone, 1993. Variations in mercury deposition to Antarctica over the past 34000 years. Nature, 362: 621-623.

Vilar, P., 1976. A History of Gold and Money, 1450-1920. NLB Press, London.

Vitruvius. On Agriculture. Translated by F. Granger, 1931. Reprinted 1962. Harvard University Press, Cambridge, MASS.

Voldner, E.C. and L. Smith, 1989. Production, Usage, and 
Emissions of Fourteen Priority Toxic Chemicals. Water Quality Board, International Joint Commission on the Great Lakes, Windsor, Ontario, $94 \mathrm{pp}$.

von Humboldt, A. 1818. Personal Narrative of the Travels to the Equinoctial Region of the New Continent during the Years 1799-1804. Reprinted 1972. Da Capo Press, New York.
Whitaker, A.P., 1952. The Elhuyar mining missions and the enlightenment. Hispanic Am. Historical Rev., 31: 570-585. WHO, 1991. Inorganic Mercury. World Health Organization. Geneva.

Wise, E.M., 1964. Gold. Van Norstrand, New York. 